\title{
Rett syndrome in childhood: the clinical characteristics
}

\author{
ES Herini , MD; Irawan Mangunatmadja , MD; Purboyo Solek, MD; \\ Hardiono D Pusponegoro, MD
}

$\mathrm{R}$ ett Syndrome (RS) was first recognized by Andreas Rett in 1966 and is a neurodevelop-mental disorder with previously unknown etiology. The syndrome is characterized by a normal psychomotor development in the early months of life, followed by the loss of psychomotor skills (especially acquired purposeful hand skills), onset of stereotypic movement in the hands, and gait disturbance. ${ }^{1}$ Classic RS has been found only in females. This syndrome has its onset at the end of the first year of life or during the first half of the second year and has a slow progressive course $^{2}$ causing devastating loss of function between infancy and the fifth year of life. Thereafter, the course becomes relatively static, setting $\mathrm{RS}$ apart from most of the genetic neurodegenerative disorders of childhood. ${ }^{3}$ An $\mathrm{x}$ chromosome gene is assumed to be responsible for the cause of RS. However, new genealogical observations suggest the involvement of autosomal recessive gene(s) as well, at least in familial cases. ${ }^{4}$

The prevalence rate of RS in various countries is from $1: 10,000$ to $1: 23,000$ female live births. ${ }^{4-11} \mathrm{RS}$ is most often misdiagnosed as autism, cerebral palsy, or non-specific developmental delay. While many health professionals may not be familiar with RS, it is a relatively frequent cause of neurological dysfunction in females. ${ }^{5}$ There are no biological markers for this disease, ${ }^{10,12}$ the diagnosis is established by history taking and clinical findings. We reported two patients, both girls, with RS.

\section{Case report}

\section{Case 1}

The patient was a 3.5 year-old girl who is the first-born child of non-consanguineous parents. Her younger brother, 22 months, was a normal child. There was no history of neurological disorder or seizure in her family. Her mother was 29 years and her father was 33 at the time of delivery. She was born fullterm without asphyxia. Birth weight and length were $2600 \mathrm{~g}$ and 46 $\mathrm{cm}$, respectively. The data of head circum-ference was not available, but her mother recalled it to be normal.

For the first 8 months, the girl was thought to be a normal child (Figure 1). Her development stagnated between 12 and 18 months old. She could sit at the age of 12 months, kneel at the age of 3 years, and could not yet walk at the present age. At the age of 8 months, she could speak two or three monosyllabic words, interact with her parents, and play with toys. Rapid deterioration of brain functions occurred after the age of 18 months. She stopped using the few sounds she had learned, lost her hand skills, became quite withdrawn

From the Departments of Child Health, Medical School, Gadjah Mada University (ESH); Padjadjaran University (PS); and University of Indonesia (IM, HDP)

Reprint requests to: ES Herini, MD, Department of Child Health, Medical School, Gadjah Mada University, Sardjito Hospital, Yogyakarta, Indonesia. Tel.62-274-561616, Fax. 62-274-583745. 


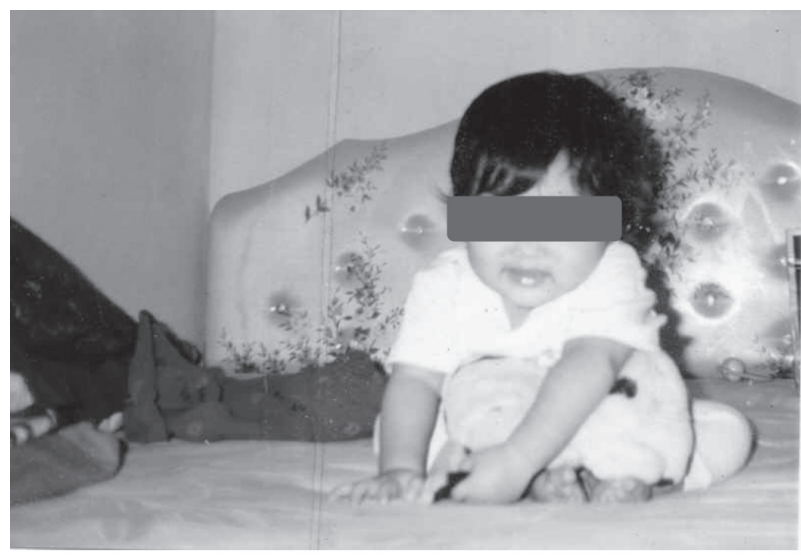

Figure 1. Case 1: Rett syndrome patient, 9 months of age, looked like a normal baby

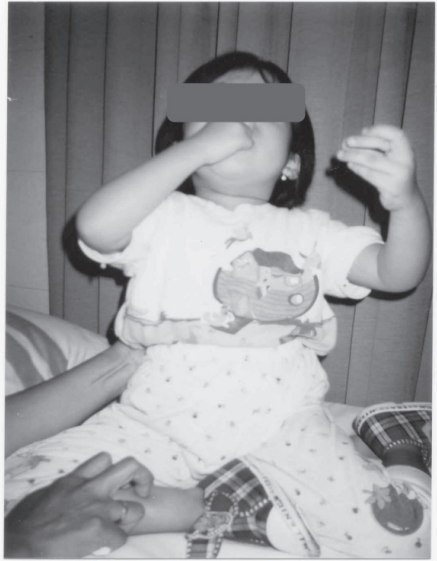

Figure 2. Case 1: Rett syndrome patient, 3.5 years of age, demonstrating hand clasping with no communication at all, and developed autistic behavior progressively. At the age of 18 months, she also began to have repetitive purposeless hand movements, clasping her hands constantly (Figure 2). On physical examination, her weight was $11.6 \mathrm{~kg}\left(<3^{\text {th }}\right.$ percentile) and height was $86 \mathrm{~cm}\left(<3^{\text {th }}\right.$ percentile). The head circumference revealed growth deceleration from about $2 \mathrm{SD}$ at the age of 2.5 years $(46 \mathrm{~cm})$ to $-2.8 \mathrm{SD}$ at the age of 3.5 years $(46 \mathrm{~cm})$, showing the evidence of acquired microcephaly. She did not have seizure; however the EEG revealed abnormalities in spikes over the right central (C4) and right parietal (P4) regions. The Computed Tomography (CT) scan showed mild cerebral atrophy (Figure 3). The Brainstem Evoked Response Audiometric (BERA) revealed normal result in the right ear and abnormal one (until $100 \mathrm{~dB}$ ) in the left ear. Although she did not suffer from seizure, carbamazepine (CBZ) was given to improve her performance.

\section{Case 2}

The patient was a 5.5 year-old girl who was the firstborn child of non-consanguineous parents with a history of developmental delay since the age of 9 months. There was no history of complication during pregnancy, labor, or delivery. Her birth weight and length were $2600 \mathrm{~g}$ and $48 \mathrm{~cm}$, respectively. The data for head circumference at birth was not available, but her mother recalled it to be normal.

She had developed well during the first 9 months of her life. She rolled over at the age of 4 months and sat with support at the age of 6 months. The patient's development stagnated between 9 to 18 months of age. Her development obviously became slower after the first year. At the age of 20 months, she became quite withdrawn with no communication at all and began to have screaming episodes. She also began to have repetitive purposeless hand movements in the form of hand clasping, hand tapping, hand wringing, and hand mouthing. She was able to stand up with support at the age of 24 months, walk with support at 36 months and without support at 5.5 years, but she showed gait apraxia (Figure 4).

The patient had rapidly lost her vocabulary and started dropping objects that she held. Her purposeful hand skills disappeared at the age of 24 months. The first seizure occurred at the age of 9 months with febrile convulsion. No seizure was then observed between 9 and 24 months of age. Myoclonic epilepsy started at the age of 24 months, which responded well to conventional antiepileptic (phenobarbital) after 32 months of treatment. She was free from seizure at the age of 4 years; however, the electroencephalography (EEG) still revealed spikes over the left frontopolar $(\mathrm{Fp} 1)$, right frontopolar (Fp2), and right frontal (F4) regions. On physical examination, her weight was $11.7 \mathrm{~kg}\left(<3^{\text {th }}\right.$ percentile) and height was $97 \mathrm{~cm}\left(<3^{\text {th }}\right.$ percentile). She had severe microcephaly with decreased head circumference from $-4 \mathrm{SD}$ at the age of 2.5 years $(43 \mathrm{~cm})$ to $5.2 \mathrm{SD}$ at 5.5 years $(44 \mathrm{~cm})$. CT scan showed microcephaly and cerebral atrophy, but the BERA result was normal. To improve performance, CBZ was adminis- 


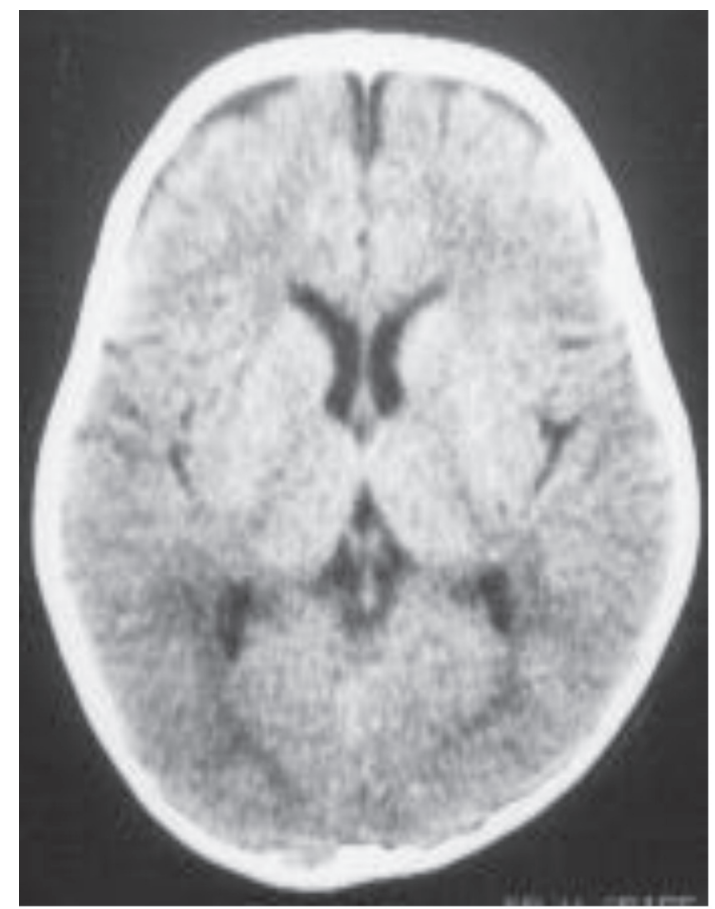

Figure 3. Case1: CT scan showed mild atrophy

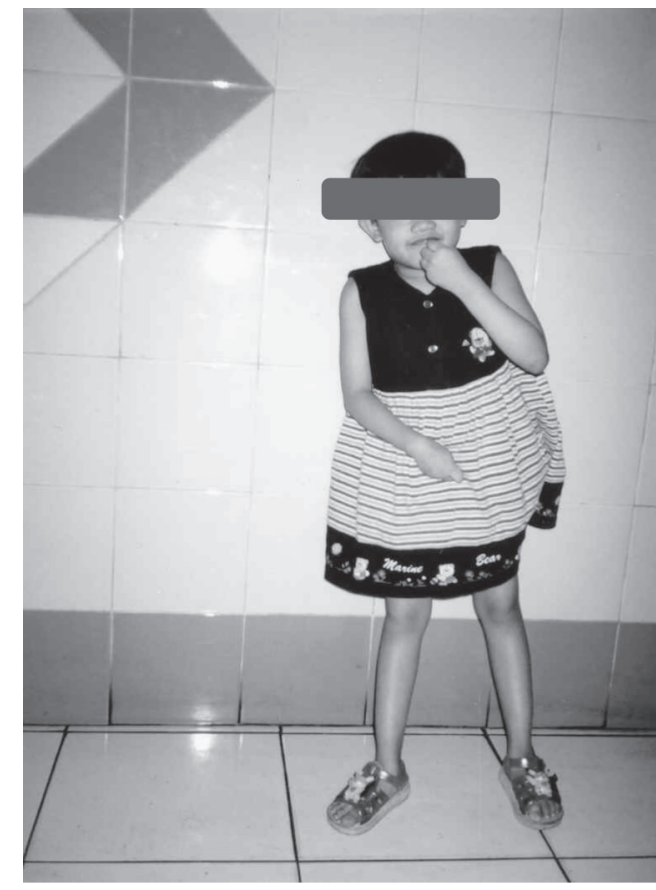

Figure 4. Case 2: Rett syndrome patient, 5.5 years of age, demonstrating hand mouthing and gait apraxia tered, but her seizure could only be eliminated with the administration of phenobarbital.

\section{Discussion}

In both of our patients, we found seven and eight of the nine necessary criteria, also five and six of the eight supportive criteria, respectively, based on Trevathan E \& Naidu S diagnostic criteria for Rett syndrome (Table 1). ${ }^{13}$

The third criterion of necessary criteria is a normal head circumference at birth. In our patients, it could not be documented because both of them were delivered by midwives. In such traditional practice, head circumferences at birth are not usually measured. Thus, the assumption made was based on the mothers' observations, which were normal in both patients.

The first patient exhibited slowing of head circumference growth from $-2 \mathrm{SD}$ at 2.5 years to -2.8 $\mathrm{SD}$ at 3.5 years, while in the second patient, the early marked slowing of head circumference growth were from $-4 \mathrm{SD}$ at 2.5 years became $-5.2 \mathrm{SD}$ at 5.5 years.
There was an obvious distinction between the first and the second patient, where at the same age $(2.5$ years) the second patient revealed severe microcephaly. This condition was consistent with the study of Jellinger et all4 which found that in nine girls with RS aged 3-17 years, the brain weight decreased to 66$88 \%$ of expected values for the age. According to Hagberg et $a l,{ }^{15}$ the mean of head growth in girls with classic RS already demonstrated a slight significant deviation from the reference population at 3 months of age and a marked one reaching 2 SD scored at 4 years of age.

Milestones for sitting, standing, and cruising may remain normal or may never take place. Independent walking is a little late or never fully matures. ${ }^{16}$ In our study, the first patient was not yet able to walk. The second patient could walk with support. Ambulation is the best motor milestone, although some will not even achieve independent sitting. It may be extremely delayed, for instance 21 years in two personal reports. ${ }^{16}$

Hand wringing may be one of the most distinctive signs of RS for pediatricians, pediatric neurologists, and patients' families. For most physicians, child psychiatrists, and other professionals treating mentally re- 
Table 1. Diagnostic criteria for Rett syndrome

\begin{tabular}{|c|c|c|}
\hline CRITERIA & Case 1 & Case 2 \\
\hline \multicolumn{3}{|l|}{ Necessary criteria } \\
\hline 1. Apparently normal prenatal and perinatal period & + & + \\
\hline 2. Apparently normal psychomotor development through the first 6 months up to 18 months & + & + \\
\hline 3. Normal head circumference at birth & $?$ & $?$ \\
\hline $\begin{array}{l}\text { 4. Deceleration of head circumference at birth, deceleration of head growth between the age of } \\
5 \text { months and } 4 \text { years }\end{array}$ & $?$ & + \\
\hline $\begin{array}{l}\text { 5. Loss of acquired purposeful hand skills between the age of } 6 \text { and } 30 \text { months, that is } \\
\text { temporarily associated with communication dysfunction and social withdrawal. }\end{array}$ & + & + \\
\hline $\begin{array}{l}\text { 6. Development of severely impaired expressive and receptive language and the presence of } \\
\text { apparent, severe psychomotor retardation }\end{array}$ & + & + \\
\hline $\begin{array}{l}\text { 7. Stereotypic hand movements such as hand wringing/squeezing, clasping/tapping, mouthing } \\
\text { and "washing"/rubbing automatisms appearing after purposeful hand skills are lost }\end{array}$ & + & + \\
\hline 8. Appearance of gait apraxia and truncal apraxia/ataxia between 1 and 4 years & + & + \\
\hline 9. Diagnosis tentative until 2 to 5 years of age & + & + \\
\hline \multicolumn{3}{|l|}{ Supportive criteria } \\
\hline 1. Breathing dysfunction & - & - \\
\hline 2. EEG abnormalities & + & + \\
\hline 3. Seizures & - & + \\
\hline 4. Spasticity, often associated with muscle wasting and dystonia & + & + \\
\hline 5. Peripheral vasomotor disturbances & - & - \\
\hline 6. Scoliosis & - & - \\
\hline 7. Growth retardation & + & + \\
\hline 8. Hypotrophic, small feet & + & + \\
\hline
\end{tabular}

tarded individual, hand wringing is seen as a common autistic or self-stimulating behavior. Hand wringing is a normal elementary stage of hand function appearing at about 14 weeks of age and not proceeding much further in RS patients. ${ }^{17}$ Generally, hand movements are performed in the midline, but occasionally, the hands may be held apart, picking at clothes, or may show hand-mouthing behaviors. ${ }^{18}$ In the first case, the patient was only able to perform hand clasping while hand wringing or hand mouthing were not detected. It means that the hands were only held apart, which showed that the hand movements were performed in the midline. It was different with the second patient who had all types of stereotypic hand movements including hand clasping, hand wringing, hand tapping, and hand mouthing.

The head CT scan showed mild cerebral atrophy in both patients. Oldfors et al ${ }^{19}$ found that cerebellar changes in RS syndrome consist of general hypoplasia with the addition of atrophy beginning in childhood and progressing over many years.

In conclusion, the younger the age, the more difficult to establish the diagnosis of Rett syndrome. History and clinical findings since delivery are very important in establishing the diagnosis.

\section{References}

1. The Rett Syndrome Diagnostic Criteria Work Group. Diagnostic criteria for Rett syndrome. Ann Neurol 1988;23:425-8.

2. Jan MMS, Dooley JM, Gordon KE. Male Rett syndrome variant: application of diagnostic criteria. Pediatr Neurol 1999;20:238-40.

3. Naidu S. Rett syndrome: a disorder affecting early brain growth. Ann Neurol 1997;42:3-9.

4. Buhler EM, Malik NJ, Alkan M. Rett syndrome and genetic drift. Brain \& Development 1999;21:175-8.

5. Rett syndrome. Description, links and books [cited 2002 Mar 8]. Available from: URL: http://www.isn.net/ -jypsy/rett.htm.

6. Singer HS, Naidu S. Rett syndrome "We'll keep the genes on for you". Neurology 2001;56:582-5.

7. Menkes JH. Heredodegenerative disease. In: Menkes $\mathrm{JH}$, Sarnat HB, editors. Child neurology. $6^{\text {th }}$ ed. Philadelpia: Lippincott Williams \& Wilkins; 2000. p. 171-239.

8. Moser HW, Naidu S. The discovery and study of Rett syndrome. In: Capute AJ, Accardo PJ, editors. Developmental disabilities in infancy and childhood. Baltimore: Paul H Brookes; 1991. p. 325-33. 


\section{Paediatrica Indonesiana}

9. Swaiman KF, Dyken PR. Degenerative diseases primarily of gray matter. In: Swaiman KF, Ashwal S, editors. Pediatric neurology principles $\&$ practice. $3^{\text {rd }}$ ed. St Louis: Mosby; 1999. p. 833-48.

10. Haslam RHA. The nervous system. In: Behrman RE, Kliegman RM, Jenson HB, editors. Nelson textbook of pediatrics. $16^{\text {th }} \mathrm{ed}$. WB Saunders Company: Philadelphia; 2000. p. 1848-5.

11. Edelson SM. Rett syndrome. Center for the Study of Autism [cited 2002 Mar 3]. Available from: URL: http:/ /www.autism.org/rett.html.

12. Matsuishi T, Nagamitsu S, Yamashita Y, Murakami Y, Kimura A, Sakai T, et al. Decreased cerebrospinal fluid levels of substance $\mathrm{P}$ in patients with Rett syndrome. Ann Neurol 1997;42:978-81.

13. Trevathan E, Naidu S. The clinical recognition \& and differential diagnosis of Rett syndrome. Journal of Child Neurology 1988;3(Suppl):6-16.
14. Jellinger K, Armstrong D, Zoghbi HY, Percy AK. Neuropathology of Rett syndrome. Acta Neuropathol 1988;76:142-58.

15. Hagberg G, Stenbom Y, Engerstrom IW. Head growth in Rett syndrome. Brain \& Development 2001;23 (Suppl):227-9.

16. Philippart M. Rett and Angelman's syndromes: models of arrested development. Pediatr Neurol 2001;25:28894.

17. Philippart M. Handwringing in Rett syndrome: a normal developmental stage. Pediatr Neurol 1992;8:197-9.

18. Percy AK. Progressive dementia associated with other neurologic abnormalities. In: Beng BO, editor. Principles of child neurology. New York: Mc Graw Hill; 1996. p. 1469-93.

19. Oldfors A, Sourander P, Armstrong DL, Percy AK, Witt-Engerstrom I, Hagberg BA. Rett syndrome: cerebellar pathology. Pediatr Neurol 1990;6:310-4. 